\title{
Assessment of Combustion and Potash Production as Options for Management of Wood Waste
}

\author{
${ }^{* 1}$ BABAYEMI J.O.; ${ }^{2}$ ADEWUYI G.O. \\ ${ }^{l}$ Department of Chemical Sciences, Bells University of Technology, Ota, Ogun State. \\ ${ }^{2}$ Department of Chemistry, University of Ibadan. \\ ${ }^{*}$ Corresponding author: Telephone: 08060709930. \\ E-mail: babayemola@yahoo.co.uk
}

\begin{abstract}
This study assessed combustion and potash production as options for management of wood waste. The percentage reduction in volume by combustion and potash generation potential of wood waste from nine different common species of wood obtained from a wood factory in Ibadan were evaluated. Potash from the ashes was extracted with distilled water through a system of filtration. The amount of ash, in kilogram per cubic metre of saw dust, and the amount of potash, in kilogram per cubic metre of ash and kilogram per cubic metre of saw dust were determined. The volume of sawdust was reduced by $95 \%$ after combustion. The ash generated ranged between $1.42-15.18 \mathrm{Kg} / \mathrm{m}^{3}$; potash yield ranged between $4.74-53.76 \mathrm{Kg} / \mathrm{m}^{3}$ of ashes and $0.21-1.53 \mathrm{Kg} / \mathrm{m}^{3}$ of saw dust. @ JASEM
\end{abstract}

Wood factories, including saw mills, are established in their thousands in various states of Nigeria, with thousands of tons of wood shavings and sawdust being generated each day (Aina, 2006). The annual wood waste generation was estimated to be 30064 $3230 \mathrm{~m}^{3}$ (Babayemi and Dauda, 2009). At present in Nigeria, apart from the insignificant use as poultry deep litters, the largest percentage of sawdust and wood shavings end up in dump sites as waste, where they are burnt and the ashes carried away by flood every year. Also, sawdust has been used as fuel for some domestic cooking. In saw mills and wood industries in Nigeria, the heaps of wood wastes are usually burnt. The ashes generated, including those from combustion of firewood in various homes and food canteens, are either land-filled or open-dumped. With time, the ashes used to fill the gulley created by erosion are eroded and transported away, since the particles are not strongly bonded together. It seems less attention is paid to the extractable component, alkali, or potash, which is a valuable resource. It was reported that out of three million tons of wood ash being generated in the United States, about $70 \%$ was being land-filled (Tarun et al., 2003) .The use of wood ash in the past had primarily been restricted to its utilization as liming agent and a source of nutrients for plant (Campbell, 1990).

Wood waste and ashes take a considerable percentage of solid wastes being generated in Nigeria every day. One of the major management problems in the megacities of Nigeria is that of solid waste disposal. Then, the use of saw dust or the product of its combustion, ashes, calls for exploration.

The importance of potash and its high demand in several countries of the world is another reason why the use of wood ash as potential source of potash must be explored. Other researchers had shown that wood contained a good percentage of potash (Irvine, 1965). Apart from the fact that the potassium hydroxide, sodium hydroxide and potassium carbonate used for soap production in Nigeria today are imported (Taiwo and Osinowo, 2001), the conventional technology is expensive and not sufficiently available in developing countries, whereas the local potash production from wood ash is cheap (Onyegbado et al., 2002) and requires no complex technology.

This report evaluates the ash and potash generation potential of wood waste, and potash production as a sustainable management option for ashes - the products of combustion of wood waste.

\section{MATERIALS AND METHODS}

Nine different saw dust samples of nine different species of wood, namely, Cola gigantia (Sp1), Ficus exasperate (Sp2), Albizia zygia (Sp3), Irvingia garbonensis (Sp4), Ceiba pentandra (Sp5), Celtis zenkeri (Sp6), Funtumia elastica (Sp7), Terminalia superba (Sp8) and Cordia millennii (Sp9), were collected from a wood factory located behind Bodija market in Ibadan.

Ash Content: A known weight $\left(\mathrm{M}_{1}\right)$ of saw dust sample, dried to constant weight in an oven set at $105^{\circ} \mathrm{C}$ (Miroslav and Vladimir, 1998) was placed in a porcelain crucible and combusted to ashes in a muffle furnace, producing mass $\mathrm{M}_{2}$ of the ash. The density $\left(D_{1}\right)$ of the saw dust sample was determined with slight modification to GEA Niro Method No. A 2a (2006) and used to find the volume $\left(\mathrm{V}_{1}\right)$ of mass $\left(\mathrm{M}_{1}\right)$ of the saw dust sample ashed, using the following relationship:

$$
V_{1}=\frac{M_{1}}{D_{1}}\left(m^{3}\right)
$$

The ash content (AC) was calculated as weight $\left(\mathrm{M}_{2}\right)$ of ash obtained per volume $\left(\mathrm{V}_{1}\right)$ of saw dust sample ashed: 
$A C=\frac{M_{2}}{V_{1}}\left(\mathrm{Kgm}^{-3}\right)$

Duplicate analysis was similarly carried out.

Potash Content (PC): Applying the method used by Kevin (2003), $0.15 \mathrm{Kg}$ of ashes produced by combustion of the sample in an open combustion pan (Onyegbado et al, 2002) was extracted with 2 litres distilled water through a filtration system composed of a series of 4-litre transparent plastic bottles. Pinholes were made at the bottom of each bottle, through which the extract solution passing through the ash sediment, dropped into some collecting buckets (Adewuyi et al, 2008). The extract solution was evaporated to complete dryness, and the residue dried in the oven set at $105^{\circ} \mathrm{C}$ for $3 \mathrm{hrs}$. It was cooled in a desicator and the weight $\left(\mathrm{M}_{4}\right)$ of the potash obtained was determined using metler balance.

The density $\left(\mathrm{D}_{2}\right)$ of the ashes was determined and used to find the volume $\left(\mathrm{V}_{3}\right)$ of the mass $\left(\mathrm{M}_{3}\right)$ of ash extracted for potash content.

$V_{3}=\frac{M_{3}}{D_{2}}\left(\mathrm{~m}^{3}\right)$
$V_{2}=\frac{M_{3}}{D_{1}}\left(\mathrm{~m}^{3}\right)$

Where $V_{2}$ equals the volume of saw dust producing $\mathrm{M}_{3}$ of ash

The potash content was calculated using the following relationships:

Potash content $\left(P C_{I}\right)$ (weight per unit volume of ash)
$P C_{1}=\frac{M_{4}}{V_{3}}\left(\mathrm{Kgm}^{-3}\right)$

Potash content $\left(\mathrm{PC}_{2}\right)$ (weight per unit volume of saw dust)

$P C_{2}=\frac{M_{4}}{V_{2}}\left(K g m^{-3}\right)$

Duplicate analysis was carried out in the same way.

Paired data t-test: Quality assurance of the results was ascertained by carrying out paired data t-test suggested by Christian (2004) on the results of the duplicates using the following relationship:

$$
T-\text { calculated }=\frac{D}{S d} \sqrt{N}
$$

Where $\mathrm{D}$ is the average of the deviations between the duplicates; $\mathrm{Sd}$ is the standard deviation of individual deviations, and $\mathrm{N}$ is the total number of samples. The results are presented under each table.

\section{RESULTS AND DISCUSSION}

Table 1 shows the result of the determination of ash generation potential, ranging between 1.62 and 15.18 $\mathrm{Kg}$ per cubic metre of saw dusts. Taking the upper value $\left(15.18 \mathrm{Kg} / \mathrm{m}^{3}\right)$ as the ash yield, it implied $1 \mathrm{~m}^{3}$ saw dust generated $15.18 \mathrm{Kg}$ ashes; if the density of the ash under consideration is taken to be $0.32 \mathrm{~g} / \mathrm{ml}$ (J.O. Babayemi, Bells University of Technology, Personal communication), the volume of ashes produced would be $0.05 \mathrm{~m}^{3}$, implying $95 \%$ reduction in volume. And assuming the wood factories generated $82368 \mathrm{~m}^{3}$ of saw dusts per day (Babayemi and Dauda, 2009), it gave $1250346.2 \mathrm{Kg}$ ash generation rate per day, and $456376363 \mathrm{Kg}$ or 1503 $216 \mathrm{~m}^{3}$ per year.

Table 1: Ash content (weight per volume of saw dust)

\begin{tabular}{llllllllll}
\hline & $\mathrm{SP} 1$ & $\mathrm{SP} 2$ & $\mathrm{SP} 3$ & $\mathrm{SP} 4$ & $\mathrm{SP} 5$ & $\mathrm{SP} 6$ & $\mathrm{SP} 7$ & $\mathrm{SP} 8$ & $\mathrm{SP9}$ \\
\hline $\mathrm{AC}\left(\mathrm{Kg} / \mathrm{m}^{3}\right)$ & 3.22 & 5.52 & 4.17 & 4.24 & 1.42 & 4.93 & 1.62 & 15.18 & 3.45 \\
\hline Duplicate $\left(\mathrm{Kg} / \mathrm{m}^{3}\right)$ & 4.14 & 6.12 & 3.80 & 3.66 & 2.69 & 5.23 & 1.59 & 15.83 & 3.26 \\
& & & & & & & & &
\end{tabular}

T-calculated $=1.403$, while the critical value $=2.306$ at $95 \%$ confidence level.

Table 2: Potash content (weight per volume of ashes)

\begin{tabular}{llllllllll}
\hline & SP1 & SP2 & SP3 & SP4 & SP5 & SP6 & SP7 & SP8 & SP9 \\
\hline $\mathrm{PC}\left(\mathrm{Kg} / \mathrm{m}^{3}\right)$ & 4.74 & 53.76 & 25.41 & 9.25 & 17.85 & 16.58 & 15.55 & 11.09 & 9.19 \\
\hline Duplicate $\left(\mathrm{Kg} / \mathrm{m}^{3}\right)$ & 4.78 & 50.09 & 27.39 & 8.67 & 18.26 & 16.30 & 15.13 & 11.29 & 9.67 \\
\hline
\end{tabular}

T-calculated $=0.420$, while the critical value $=2.306$ at $95 \%$ confidence level.

Table 3: Potash content (weight per volume of saw dust)

\begin{tabular}{|c|c|c|c|c|c|c|c|c|c|}
\hline & SP1 & $\mathrm{SP} 2$ & SP3 & SP4 & SP5 & SP6 & SP7 & SP8 & SP9 \\
\hline $\mathrm{PC}\left(\mathrm{Kg} / \mathrm{m}^{3}\right)$ & 0.36 & 1.53 & 0.43 & 0.35 & 0.30 & 0.33 & 0.21 & 0.44 & 0.25 \\
\hline Duplicate $\left(\mathrm{Kg} / \mathrm{m}^{3}\right)$ & 0.36 & 1.42 & 0.47 & 0.32 & 0.31 & 0.32 & 0.20 & 0.45 & 0.24 \\
\hline
\end{tabular}

T-calculated $=0.570$, while the critical value $=2.306$ at $95 \%$ confidence level. 
Results of potash yield of the ashes are presented in Table 2. The yield ranged between 4.74 and $53.76 \mathrm{Kg}$ of potash per cubic metre of ashes. Taking $53.76 \mathrm{Kg} / \mathrm{m}^{3}$ as the potash yield of the ashes, 1503 $216 \mathrm{~m}^{3}$ of ashes will yield approximately 80812 $892 \mathrm{Kg}$ of potash annually, which is more than meeting the country's annual demand for potash.

Potash contents per volume of saw dust are shown in Table 3, ranging between 0.21 and $1.53 \mathrm{Kg}$ per cubic metre of saw dusts. The yield appears to be small, but if compared to the annual wood waste output as discussed above, it is highly significant.

Duplicate analysis of each experiment was carried out and the results shown in the third rows of each table. As shown in the footnote under each table, statistical analysis showed that there was no significant difference in the results of the duplicate analysis.

Conclusively, wood waste volume could be reduced by $95 \%$ after combustion and the resulting ashes could serve as a source of the much needed potash in the production of soap and other potash-based materials.

\section{REFERENCES}

Adewuyi, GO; Obi-Egbedi, NO; Babayemi, JO (2008). Evaluation of ten different African wood species for potash production. International Journal of Physical Science, 3(3): 63-68.

Aina, OM (2006). Wood waste utilization for energy generation. Proceedings of the International Conference on Renewable Energy for Developing Countries, 2006.

Babayemi, JO; Dauda, KT (2009). Evaluation of solid waste generation, categories and disposal options in developing countries: a case study of Nigeria. J. Appl. Sci. Environ. Manage. 13(3): 83-88.
Campbell, AG (1990). Recycling and disposing of wood ash. Tappi 73 (9): 141-146.

Christian GD (2004). Analytical Chemistry. John Wiley \& Sons (Asia) Ltd., Singapore. 6th Edition. Pp. 97.

GEA Niro Analytical Method No. A 2a (2006). Powder Bulk Density.

Irvine, FR (1965). West African Crops. Oxford University Press. $3^{\text {rd }}$ Edition, 97-114.

Kevin, MD (2003). 28 Projects from the creation of fire to the production of plastics. Caveman Chemistry. Retrieved from www.cavemanchemistry.com

Miroslav, R; Vladimir, N B (1998). Plant analysis. Practical Environmental Analysis. Pp. 379-397.

Onyegbado, CO; Iyagba, ET; Offor, OJ (2002). Solid soap production using plantain peels ash as source of alkali. Journal of Applied Science and Environmental Management. 6 (1): 73-77.

Taiwo, OE; Osinowo, FAO (2001). Evaluation of various agro-wastes for traditional soap production. Bioresource Technol 79 (1), 95-97.

Tarun, RN; Rudolf, NK; Rafat, S (2003). Use of wood ash in cement-based materials. CBU-2003 -19 .

* Corresponding author: ${ }^{* 1}$ Babayemi J.O. 